\title{
Solitary Peripheral Osteoma of the Hard Palate Case report and literature review
}

"Fotios Bountaniotis, Ioannis Melakopoulos, Fotios Tzerbos

$$
\text { الأورام العظمية الطرفية الإنفرادية للحنك الصلب }
$$

فوتيوس بونتانيوتيس، إيونيس ميلاكوبولوس، فوتيوس تزيربوس

ABSTRACT: Osteomas are benign slow-growing osteogenic lesions of unknown aetiology which can be central, peripheral or extraskeletal. Peripheral osteomas of the maxilla are very uncommon. We report a 72-year-old female patient who presented to the Department of Oral \& Maxillofacial Surgery, Dental School of Athens, Athens, Greece, in 2015 with swelling of the palate following a tooth extraction. Clinical and radiographical features were indicative of a solitary peripheral osteoma of the hard palate. An excisional biopsy and histological examination of the lesion confirmed the diagnosis. No complications occurred during the postoperative period and there was no evidence of recurrence at a one-year follow-up.

Keywords: Bone Tissue Neoplasms; Osteomas; Maxilla; Hard Palate; Case Report; Greece.

$$
\begin{aligned}
& \text { الملخص: الأورام العظمية من الآفات الحميدة بطيئة النمو الغير معروفة السبب و يمكن أن تكون مركزية، طرفية أو خارج الجهازالعة العظمي. }
\end{aligned}
$$

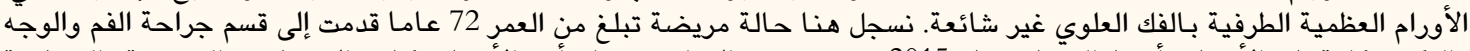

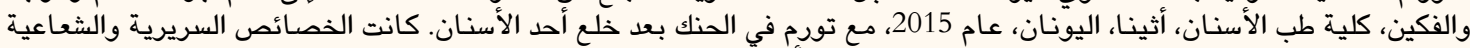

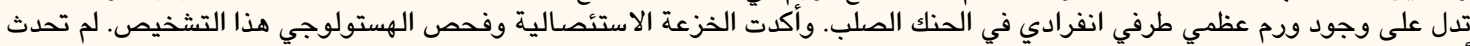

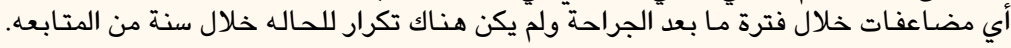

$$
\begin{aligned}
& \text { الكلمات المفتاحية: أورام الأنسجة العظمية؛ الأورام العظمية؛ الفك العلوي؛ الحنك الصلب؛ تقرير حالة؛ اليونان. }
\end{aligned}
$$

$\mathrm{O}$ STEOMAS ARE BENIGN OSTEOGENIC LESIONS predominantly found in the craniomaxillofacial bones which can be central, peripheral or extraskeletal, arising either from the endosteum, periosteum or soft tissues, respectively. ${ }^{1,2}$ Peripheral osteomas of the jaw bones are quite rare and usually remain asymptomatic until they cause asymmetry or compression of the adjacent structures due to their progressive growth. ${ }^{1-3}$ Although developmental, infectious, traumatic and neoplastic theories have been proposed, the exact aetiology of these lesions is still unknown. ${ }^{4,5}$ Osteomas have been reported to arise from bone graft sites. ${ }^{6}$ Multiple maxillofacial osteomas can also occur among patients with Gardner's syndrome. ${ }^{5,7,8}$ This report presents a rare case of solitary peripheral osteoma of the hard palate, followed by a comprehensive literature review.

\section{Case Report}

A 72-year-old female patient presented to the Department of Oral \& Maxillofacial Surgery, Dental School of Athens, Athens, Greece, in 2015 with complaints of swelling of the palate following extraction of her upper right second molar. Eight months earlier, she had noticed a slowly growing asymptomatic mass in the palate at the site of the extraction. She had a medical history of hypothyroidism, diabetes mellitus, arterial hypertension, hypercholesterolaemia, osteopaenia and phlebitis. A clinical examination revealed a well-defined firm bony painless mass of approximately $2 \mathrm{~cm}$ in diameter located in the posterior right part of the hard palate. The overlying mucosa was intact with no ulcerations, associated pain or changes in colour [Figure 1A]. Cone-beam computed tomography $(\mathrm{CBCT})$ revealed a well-defined 'mushroom'-like exophytic pedunculated radiopaque lesion originating from the palatine bone [Figure 2]. A comprehensive examination for Gardner's syndrome was negative.

Based on the clinical and radiographical findings, a diagnosis of a peripheral osteoma was made and an excisional biopsy was performed. Under local anaesthesia, a mucosal incision was made and a fullthickness flap was elevated. The lesion was wellcircumscribed and attached by a pedicle to the adjacent alveolar bone of the palate. Using a chisel and mallet, the lesion was removed and the surgical site debrided. The flap was closed with non-absorbable 

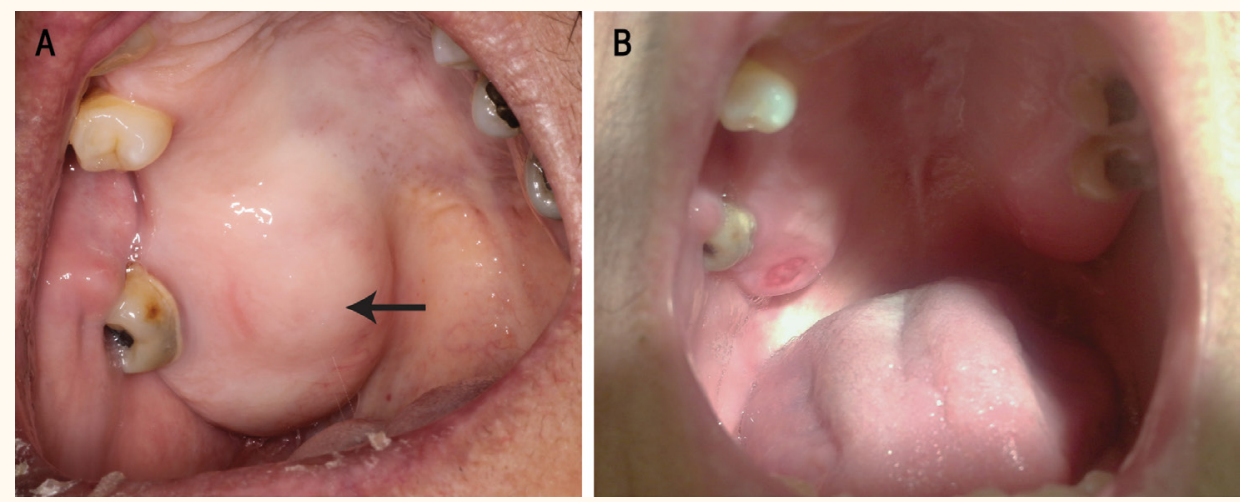

Figure 1: Intraoral photographs of the oral cavity of a 72-year-old female patient (A) at presentation showing a welldefined firm bony painless mass (arrow) in the posterior right part of the hard palate covered by intact mucosa and (B) one year after the successful excisional biopsy of a solitary peripheral osteoma of the hard palate.

3-0 silk sutures. There were no postoperative complications. A histopathological examination revealed mature compact and cancellous bone with marrow spaces and osteocytes, confirming the diagnosis of a peripheral osteoma [Figure 3]. At a one-year follow-up, the patient had healed completely and there was no evidence of recurrence [Figure 1B].

\section{Discussion}

According to Boffano et al., patients with osteomas have a mean age of 48 years and the male-to-female ratio is $0.4: 1 .{ }^{9}$ In the jaws, osteomas appear either on the surface of the bones, as pedunculated and sessile masses arising from the periosteum, or in the medullary space arising from the endosteum.,4,10 Peripheral osteomas of the maxillofacial area are rare, appearing mainly in the paranasal sinuses; the most common site is the frontal sinus, followed by the ethmoidal and maxillary sinuses. ${ }^{8,11}$ Solitary peripheral osteomas of the jaw bones are very uncommon and generally involve the mandible more often than the maxilla. ${ }^{1-3,12}$ Clinical symptoms of an osteoma depend on the location, size and direction of tumour growth; generally, osteomas of the maxillofacial bones remain asymptomatic until they grow large enough to

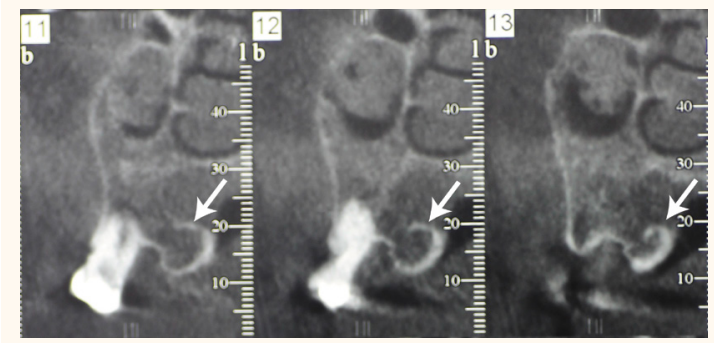

Figure 2: Cone-beam computed tomography of a 72-year-old female patient with swelling of the palate showing a 'mushroom'-like exophytic radiopaque mass originating from the palatine bones (arrows). cause disfigurement or compression of the adjacent structures..$^{1-3}$ Neurological symptoms caused by nerve compression may also occur. ${ }^{3,13}$

On histology, osteomas may be either compact or cancellous masses. Compact osteomas usually have a sessile base with normal-appearing dense bone, while cancellous osteomas are generally pedunculated and resemble the bone of origin. ${ }^{14,15}$ Radiographically, peripheral osteomas appear as wellcircumscribed pedunculated or sessile radiopaque masses which seem to have normal bone density. ${ }^{16}$ In cases of superimposition of the lesion on imaging, CBCT can be useful. ${ }^{17}$ However, it may be difficult to differentiate peripheral osteomas from other lesions using imaging techniques; the differential diagnosis includes peripheral ossifying fibromas, exostoses, sessile osteochondromas, osteoid osteomas, periosteal osteoblastomas and parosteal osteosarcomas. ${ }^{4,5,15}$ The patient's medical history and clinical characteristics of the lesion can be helpful in distinguishing a peripheral osteoma from an exostosis, even though there are no histological differences between the two entities; an osteoma will continue to grow during adulthood, unlike exostoses, which usually stop growing after puberty., ${ }^{5,1418}$ In addition, the osteoid subtype of

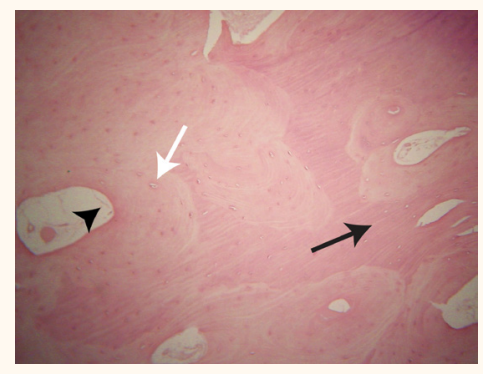

Figure 3: Haematoxylin and eosin stain at x200 magnification showing a osteoma consisting of lamellar bone (black arrow), osteocytes (white arrow) and marrow spaces (arrowhead). 
osteomas usually grows rapidly and is painful. ${ }^{14,19} \mathrm{~A}$ periosteal osteoblastoma has similar characteristics in terms of growth rate and symptoms. ${ }^{14,19}$ Similar to an osteoma, a peripheral ossifying fibroma appears as a radiopaque mass; however, it does not intrude into the cortical bone. ${ }^{15,19}$

In the current case, the clinical and radiographical features were indicative of a peripheral osteoma. It is difficult to clinically and histologically differentiate an osteoma from torus palatinus; however, the latter is usually located in the midline of the hard palate..$^{19,20}$ It is worth mentioning that the patient in the present case had undergone a tooth extraction in the area of the osteoma a few months previously; however, it is not clear if this trauma was related to the aetiology of the lesion. Although asymptomatic osteomas are treated conservatively with regular follow-up, surgical excision is necessary if the lesion becomes symptomatic, grows too large or is indicated for cosmetic reasons. ${ }^{3}$ The surgical removal of osteomas is usually performed with a chisel and mallet, as in the present case, although rotary instruments can also be used. Following the surgery, recurrence of the lesion is extremely uncommon and malignant transformation has not been reported to date.,11

The appearance of an osteoma in the maxillofacial region should raise suspicions of Gardner's syndrome; this conditions consists of multiple peripheral and/or central osteomas in any bone-most frequently those in the craniomaxillofacial area-as well as cutaneous sebaceous cysts, desmoid tumours, multiple supernumerary teeth and colorectal polyposis. ${ }^{5,7,8}$ Symptoms may also include rectal bleeding, diarrhoea and abdominal pain. In patients with Gardner's syndrome, the osteomas often develop before the colorectal polyposis; therefore, an early diagnosis is of paramount importance. ${ }^{2,3,7}$ The patient in the current case underwent a thorough examination for Gardner's syndrome, which was eventually ruled out.

\section{Conclusion}

Peripheral osteomas of the jaws are relatively uncommon and dentists and maxillofacial surgeons should be aware of the differential diagnosis and clinical characteristics of these lesions. Multiple osteomas can be indicative of Gardner's syndrome; as such, an early diagnosis can be very important for the patient's prognosis. Osteomas are treated conservatively in asymptomatic cases, but may require surgical excision when indicated.

\section{References}

1. Woldenberg Y, Nash M, Bodner L. Peripheral osteoma of the maxillofacial region: Diagnosis and management - A study of 14 cases. Med Oral Patol Oral Cir Bucal 2005; 10:E139-42.

2. Shakya H. Peripheral osteoma of the mandible. J Clin Imaging Sci 2011; 1:56. doi: 10.4103/2156-7514.90483.

3. Sharma D, Sathe S, Rawat B, Agrawal D, Khasgiwala A, Shakya N. A study on peripheral osteomas of the maxillofacial region. J Evol Med Dent Sci 2015; 4:8545-51. doi: 10.14260/ jemds/2015/1237.

4. Prabhuji ML, Kishore HC, Sethna G, Moghe AG. Peripheral osteoma of the hard palate. J Indian Soc Periodontol 2012; 16:134-7. doi: 10.4103/0972-124X.94623.

5. Gundewar S, Kothari DS, Mokal NJ, Ghalme A. Osteomas of the craniofacial region: A case series and review of literature. Indian J Plast Surg 2013; 46:479-85. doi: 10.4103/0970-0358. 121982.

6. Colletti G, Autelitano L, Rabbiosi D, Tewfik K, Frigerio A, Biglioli F. Parosteal osteoma arising in an iliac bone graft used for mandibular reconstruction. J Oral Maxillofac Surg 2012; 70:e477-80. doi: 10.1016/j.joms.2012.03.008.

7. Boffano P, Bosco GF, Gerbino G. The surgical management of oral and maxillofacial manifestations of Gardner syndrome. J Oral Maxillofac Surg 2010; 68:2549-54. doi: 10.1016/j.joms. 2009.09.084

8. Lew D, DeWitt A, Hicks RJ, Cavalcanti MG. Osteomas of the condyle associated with Gardner's syndrome causing limited mandibular movement. J Oral Maxillofac Surg 1999; 57:1004-9. doi: 10.1016/S0278-2391(99)90026-5.

9. Boffano P, Roccia F, Campisi P, Gallesio C. Review of 43 osteomas of the craniomaxillofacial region. J Oral Maxillofac Surg 2012; 70:1093-5. doi: 10.1016/j.joms.2011.05.006.

10. Iwai T, Izumi T, Baba J, Maegawa J, Mitsudo K, Tohnai I. Peripheral osteoma of the mandibular notch: Report of a case. Iran J Radiol 2013; 10:74-6. doi: 10.5812/iranjradiol.3734.

11. Hu W, Thadani S, Agrawal M, Sharma N, Tailor S. Peripheral osteoma of the palate: Report of a case and review of literature. J Clin Diagn Res 2014; 8:ZD29-31. doi: 10.7860/ JCDR/2014/7888.5351

12. Bulut E, Acikgoz A, Ozan B, Gunhan O. Large peripheral osteoma of the mandible: A case report. Int J Dent 2010; 2010:834761. doi: 10.1155/2010/834761

13. Ogbureke KU, Nashed MN, Ayoub AF. Huge peripheral osteoma of the mandible: A case report and review of the literature. Pathol Res Pract 2007; 203:185-8. doi: 10.1016/j. prp.2007.01.004

14. Manjunatha BS, Das N, Sutariya R, Ahmed T. Peripheral osteoma of the body of mandible. BMJ Case Rep 2013; 2013:bcr2013009857. doi: 10.1136/bcr-2013-009857.

15. Johann AC, de Freitas JB, de Aguiar MC, de Araújo NS, Mesquita RA. Peripheral osteoma of the mandible: Case report and review of the literature. J Craniomaxillofac Surg 2005; 33:276-81. doi: 10.1016/j.jcms.2005.02.002.

16. Durão AR, Chilvarquer I, Hayek JE, Provenzano M, Kendall MR. Osteoma of the zygomatic arch and mandible: Report of two cases. Rev Port Estomatol Cir Maxilofac 2012; 53:103-7. doi: 10.1016/j.rpemd.2012.02.006

17. Boffano P, Gallesio C, Roccia F, Berrone S. Radiographic superimposition and mandibular peripheral osteoma: The importance of clinical and CT findings. J Craniofac Surg 2013; 24:e141-2. doi: 10.1097/SCS.0b013e31827c7e87. 
18. Rodriguez y Baena R, Rizzo S, Fiandrino G, Lupi S, Galioto S. Mandibular traumatic peripheral osteoma: A case report. Oral Surg Oral Med Oral Pathol Oral Radiol Endod 2011; 112:e44-8. doi: 10.1016/j.tripleo.2011.05.006.

19. Soni S, Bhargava A. Revisiting peripheral osteoma of the mandible with case series and review of literature. Indian J Otolaryngol Head Neck Surg 2014; 66:212-18. doi: 10.1007/ s12070-012-0583-9.
20. Apinhasmit W, Jainkittivong A, Swasdison S. Torus palatinus and torus mandibularis in a Thai population. ScienceAsia 2002; 28:105-11. 